\title{
Evolução dos verbos auxiliares na língua portuguesa
}

\author{
Evolution of the Auxiliary Verbs in Portuguese Language
}

\author{
Jan Hricsina [Jan.hricsina@ff.cuni.cz] \\ Univerzita Karlova, República Checa
}

\begin{abstract}
RESUMO
O presente artigo trata da evolução dos verbos auxiliares na língua portuguesa. Visto que esta problemática é muito complexa, o artigo segue vários objetivos: 1. verificar qual o emprego dos verbos auxiliares na evolução do Português Europeu; 2. mostrar a evolução da concordância do particípio com o objeto direto ou sujeito; 3. desvendar a relação entre o tempo composto e construção resultativa e as suas caraterísticas morfossintáticas, sobretudo no Português Antigo; 4. mostrar a evolução do significado tempo-aspetual do pretérito perfeito composto no Português Europeu. A pesquisa foi realizada tendo por base o corpus linguístico que permite fazer análises diacrónicas $w w w$.corpusdoportugues.org.
\end{abstract}

\section{Palavras-chave}

verbo auxiliar; pretérito perfeito composto; língua portuguesa; linguística diacrónica; corpus linguístico.

\begin{abstract}
The topic of this article is the evolution of auxiliary verbs in Portuguese. Due to the complexity of this question, the article has several objectives: 1 . to verify the use of auxiliary verbs in the evolution of European Portuguese; 2 . to show the evolution of the concordance of the participle with the direct object or subject; 3. to analyze the relationship between composite time and the resultant construction and its morpho-syntactic characteristics, especially in Old Portuguese; 4. to show the evolution of the temporal/ aspectual sense of the compound past perfect in European Portuguese. The research was carried out in the linguistic corpus that allows to make diachronic analyses www.corpusdoportugues.org.
\end{abstract}

KEYWORDS

Auxiliary verb; compound past perfect; Portuguese language; diachronic linguistics; linguistic corpus.

RECEBIDO 2016-12-08; ACEITE 2017-01-28

Este artigo teve o apoio do projeto da Universidade Carolina Progres 4, A Língua nas mudanças de tempo, espaço e cultura. 


\section{Introdução}

Um dos critérios segundo o qual se podem dividir as línguas românicas atuais é o caráter morfológico, morfossintático ou semântico dos tempos compostos. O primeiro critério pode ser representado pelo número de verbos auxiliares que são usados na formação dos tempos compostos. Considerando este aspeto, podemos separar as línguas românicas em dois grupos principais: o primeiro é formado pelas línguas que usam só um verbo auxiliar (Castelhano, Romeno, Catalão, Galego'); o segundo grupo é representado pelos idiomas em que existem dois verbos auxiliares (Português ${ }^{2}$, Francês, Italiano ${ }^{3}$ ). O segundo critério está relacionado com o tipo do verbo auxiliar. As línguas que têm só um verbo auxiliar, usam geralmente o verbo habere (Castelhano, Romeno, Catalão, Sardo). Algumas línguas românicas, porém, substituíram o verbo habere pelo verbo tenere (Português, Galego, Asturiano). As línguas com dois verbos auxiliares usam sempre os verbos habere e esse $e^{4}$ (Francês, Italiano, Aragonês, Occitano, Franco-provençal, Reto-romano). Nestas línguas, o particípio passado concorda, seja com o objeto direto que o precede (nos tempos compostos formados pelo verbo auxiliar habere), seja com o sujeito (com o verbo esse). Nas línguas com só um verbo auxiliar não se verifica nenhuma concordância nos tempos compostos. O último critério apoia-se no significado tempo-aspetual expresso pelo pretérito perfeito composto. Este tempo composto costuma exprimir uma ação passada terminativa (Castelhano, Francês, Romeno, Aragonês, Franco-provençal, Sardo). Nalgumas línguas românicas, este paradigma exprime uma ação passada terminativa relacionada com o presente (Italiano, Catalão, Occitano). Nas línguas com o único verbo auxiliar tenere, o pretérito perfeito composto exprime geralmente uma ação passada reiterativa (Galego, Asturiano). Em Português, este paradigma denota uma ação durativa ou reiterativa que começou num momento do passado geralmente indeterminável e que dura até ao momento presente e há possibilidade de esta ação ou estado se prolongar até ao futuro.

Vimos, assim, que na língua portuguesa se observa uma situação específica, em termos de tempos compostos, relativamente às demais línguas românicas. O Português tem dois verbos auxiliares (o verbo haver com algumas restrições de emprego). O particípio passado nunca concorda nem com o objeto direto, nem com o sujeito. $\mathrm{O}$ último aspeto específico é representado pelo significado tempo-aspetual diferente dos outros idiomas neolatinos. Nas fases antigas do Português, a situação, porém, era diferente. Havia mais verbos auxiliares (haver, ter e ser), o particípio passado concordava com os objetos direto e sujeito e o significado do pretérito perfeito composto era semelhante ao das línguas românicas atuais. O objetivo deste artigo é, assim, analisar a evolução específica da formação do tempo composto em Português, mostrar qual o emprego dos verbos auxiliares na história da língua portuguesa, apresentar a evolução da concordância do particípio passado com o objeto direto e com o sujeito. A nossa análise

1 Para além destas línguas só um verbo auxiliar existe também no Asturiano e no Sardo (Hricsina 2014: 170171).

2 A língua portuguesa dispõe de dois verbos auxiliares usados na formação dos tempos compostos: ter e haver. No entanto, o último pode-se empregar apenas no mais-que-perfeito composto e geralmente na língua escrita.

3 Ao lado destas línguas, há dois verbos auxiliares também em Aragonês, Occitano, Franco-provençal e Retoromano (Hricsina 2014: 170-171).

4 Com exceção do Português, ver a nota 3. 
deverá apontar também a relação entre o tempo composto e a construção resultativa no Português Antigo e mostrar eventualmente a evolução do significado tempo-aspetual do pretérito perfeito composto em Português. A análise será realizada no corpus linguístico que permite fazer as pesquisas diacrónicas $w w w$.corpusdoportugues.org.

\section{Evolução dos verbos auxiliares no Português Europeu}

A evolução dos verbos auxiliares no Português Europeu é uma problemática muito complexa porque tem vários aspetos interligados a considerar. O primeiro aspeto que vamos tratar, consiste na descrição da evolução do inventário destes verbos durante a história da língua portuguesa e nas mudanças verificadas no seu emprego. Este aspeto relaciona-se com as transformações de uso sofridas no subsistema dos verbos ser, estar, haver e ter. Outra questão que merece ser analisada, é a formação do tempo composto em Português, ou seja, o processo da sua gramaticalização, e a sua definição. Este problema está ligado à relação entre o tempo composto e a construção resultativa. A última questão a esclarecer é o significado tempo-aspetual do pretérito perfeito composto português que é muito específico no contexto das línguas românicas.

Como já foi referido, o Português Contemporâneo dispõe de dois verbos auxiliares usados na formação dos tempos compostos, respetivamente ter e haver. No entanto, o verbo auxiliar haver tem certas limitações de uso, reduzindo-se o seu emprego ao pretérito mais-que-perfeito composto e quase exclusivamente ao registo escrito (O Pedro tinha/havia escrito uma carta à Maria. $^{5}$ ) (Raposo 2013: 62). No Português Antigo ${ }^{6}$, o inventário de verbos auxiliares era maior. Além dos verbos ter e haver, empregava-se como auxiliar também o verbo ser. Os dois primeiros auxiliares (ter e haver) usavam-se para formar tempos compostos dos verbos transitivos, enquanto que o verbo ser era empregue com os verbos intransitivos (morrer, nascer, passar) ou de movimento (partir, chegar, vir) 7 . O emprego dos três auxiliares teve uma evolução dinâmica. No Português Antigo, o auxiliar haver era muito mais frequente do que o verbo ter. Só a partir do século XV, o verbo ter começa a aparecer como auxiliar com cada vez maior frequência e vai substituindo o auxiliar original haver (Brocardo 2014: 135; Berta 2016: 182). As construções com o verbo auxiliar ser desapareceram por completo mais tarde ${ }^{8}$.

Como já foi mencionado, a mudança dos verbos auxiliares em Português está relacionada com a reorganização do funcionamento geral dos verbos ser, estar, haver e ter. No Português Antigo, estes verbos usavam-se duma maneira muito diferente se comparados com o seu uso na língua atual. O verbo haver empregava-se nas construções existenciais, possessivas e funcionava também como verbo auxiliar. $\mathrm{O}$ verbo ter pode ter figurado nas estruturas possessivas

5 Os exemplos em que não figura nenhuma indicação de fonte, provêm do uso do Português Contemporâneo.

6 Pelo Português Antigo entendemos a língua usada no Reino de Portugal desde os finais do século XII até meados do século XVI.

7 O linguista brasileiro Said Ali vê a origem destas construções com o verbo ser nos tempos compostos dos depoentes latinos (Mattos e Silva 1989: 447).

8 Segundo a linguista portuguesa Maria Teresa Brocardo, o verbo auxiliar ser deixou de ser usado só quando as construções com os verbos auxiliares haver e ter foram plenamente gramaticalizadas (Brocardo 2014: 143). 
e usava-se também como auxiliar. O verbo ser empregava-se nas construções locativas e possessivas e funcionava também como verbo auxiliar e como verbo copulativo com predicados estáveis e episódicos. O verbo estar entrava também nas estruturas locativas e funcionava como copulativo com predicados episódicos (Raposo 2013: 40-45). No Português Contemporâneo, estes verbos têm um emprego diferente. O verbo haver só se usa como verbo existencial, enquanto o verbo ter entra nas construções possessivas e funciona como verbo auxiliar ${ }^{9}$. O verbo ser tem o emprego locativo e possessivo e funciona também como verbo copulativo com predicados estáveis. O verbo estar é também um verbo locativo, mas usa-se com predicados episódicos. O emprego dos verbos ter e haver no Português Antigo é analisado pela linguista portuguesa Maria Teresa Brocardo que refere que ambos os verbos entravam nas estruturas de posse, mas cada um tinha um conteúdo diferente. $\mathrm{O}$ verbo haver exprimia a posse inerente ou permanente, enquanto o verbo ter denotava a posse não-inerente ou transitória (Brocardo 2014: 132-135). A mesma autora acrescenta ainda que os dois verbos eram mais gramaticalizados do que o verbo possuir. Os dois verbos funcionavam também como verbos leves, ou seja, "não predicavam nestes casos de forma plena, diferentemente do que acontece em estruturas tradicionalmente referidas como de posse" (ter uma casa - estrutura de posse tradicional/ter uma discussão com ele - verbo leve) (Brocardo 2014: 135). As ocorrências destes verbos no contexto de verbos leves eram, porém, diferentes em várias etapas do Português Antigo. Enquanto o verbo haver é típico das construções em questão já na fase inicial do Português Antigo, o verbo ter começa a aparecer neste tipo de estruturas só no século XV. Tal pode acontecer só quando ocorre um esvaziamento lexical ou uma generalização do sentido de um verbo, neste caso, do verbo ter. Isso permitirá também ao verbo ter começar a generalizar-se como verbo auxiliar. E, como vimos atrás, tal acontece no mesmo período.

Acerca da formação do pretérito perfeito composto nas línguas românicas, considera-se que este tempo começou a formar-se já no Latim Vulgar e provém da construção resultativa. Observe-se o exemplo clássico que está citado em muitas obras que tratam da evolução do Latim Vulgar: in ea provincia pecunias magnas collocatas habent (Cícero) (Ribeiro 1996: 344). As caraterísticas sintáticas destas construções são as seguintes:

1. concordância do particípio com o objeto direto (pecunias collocatas)

2. possibilidade de intercalação de vários elementos entre o verbo auxiliar e o particípio (tenho a carta já escrita)

3. anteposição do objeto direto ao particípio (tenho a carta escrita)

Vários historiadores da língua portuguesa têm considerado a perda destas caraterísticas formais, sobretudo a perda da concordância do particípio com o objeto direto, como um traço essencial da transformação da estrutura resultativa em tempo composto (Said Ali, Mattoso Câmara Jr. ${ }^{10}$, Mattos e Silva entre outros). Porém, a situação não é tão simples como possa parecer. Há duas línguas românicas, a francesa e a italiana, em que a concordância participial, em

9 No Português do Brasil, o verbo ter funciona como verbo existencial em vez do verbo haver.

10 Os linguistas brasileiros Said Ali e Mattoso Câmara Jr. afirmavam que, desde que haja a concordância do particípio passado com o objeto, não se trata de tempo composto (Mattos e Silva 1989: 438). 
contextos específicos ${ }^{11}$, se conservou até hoje. Ainda por cima, alguns estudos mais recentes demonstraram que já no Português Antigo existiam tempos compostos com a concordância participial (Cardoso e Pereira 2003). Segundo estas autoras, na abordagem dos tempos compostos em Português, a análise semântica baseada em contrastes temporais e aspetuais é mais profícua do que critérios formais. É este método que queremos aproveitar também no presente artigo.

Agora vamos ver qual é a relação entre o tempo composto e a construção resultativa no Português Antigo. Acima foi referido que o pretérito perfeito composto se originou de construções resultativas, mas é preciso acrescentar que estas não desapareceram em Português como aconteceu nalgumas línguas românicas (Francês, Italiano).

No Português Antigo, as construções resultativas eram formadas por dois verbos, respetivamente ter e haver. O primeiro verbo era muito mais frequente, enquanto que o verbo haver se empregava com maior frequência em tempos compostos. Esta distribuição pode ser causada pelo valor de duratividade que possui o verbo ter (Cardoso e Pereira 2003: 166). A distinção entre o pretérito perfeito composto e a construção resultativa baseava-se sobretudo na escolha do verbo auxiliar ou semiauxiliar (haver/ter). Com a substituição progressiva do verbo auxiliar haver dos tempos compostos pelo verbo ter, a diferenciação entre o tempo composto e a construção resultativa era cada vez mais difícil. Na maioria dos casos, ambas as estruturas tinham o mesmo verbo auxiliar ou semiauxiliar ter e o particípio concordava com o objeto direto. E é nesta ameaça da distinção formal entre as duas construções que o linguista húngaro Tibor Berta vê o motivo principal da aceleração do processo da não-concordância do particípio com o objeto direto (Berta 2016). Da sua análise ${ }^{12}$ resulta que, no século XIV, o verbo haver se usava sobretudo como verbo auxiliar do pretérito perfeito composto e o verbo ter em construções resultativas. No século XV, o verbo haver funcionava sempre como verbo auxiliar dos tempos compostos, mas o verbo ter já pode ter figurado seja em tempos compostos seja em construções resultativas. No século XVI, só se usa o verbo ter nas duas funções (Berta 2016: 182).

O processo em que uma construção sintaticamente livre (ele tem todos os livros já lidos) passa a um tempo composto (ele tem lido livros), é tradicionalmente designado pelo termo gramaticalização. Este tipo de mudança linguística tem sido estudado por vários linguistas. Em linhas gerais, pode ser definido pelas palavras do linguista inglês Ian Roberts: "Grammaticalization is a change from a lexical to a functional category (with associated semantic bleaching)" (Ribeiro 1996: 346). É um processo que tem geralmente várias fases:

1. verbo pleno

2. construção predicativa

3. forma perifrástica

4. aglutinação

11 Nestas línguas, o particípio concorda com o sujeito da frase quando o verbo auxiliar é representado pelo verbo être ou essere (elle est arrivée). O particípio concorda com o objeto direto no caso de o último estar anteposto ao particípio ( $i$ libri che ho letti).

12 No seu estudo, o autor analisou três textos, cada um proveniente de diferentes séculos: Crónica Geral de Espanha (século XIV), História do mui Nobre Vespasiano Imperador de Roma (século XV) e Crónica dos Reis de Bisnaga (século XVI). 
Todo este processo dura comummente vários séculos. Para demonstrá-lo, podemos servirnos do exemplo da evolução do futuro simples português. Em Latim, havia verbo pleno habere que exprimia o significado de posse (habeo pecuniam) (1. a fase). Na segunda fase, o verbo habere começou a usar-se com vários verbos de pleno significado com o objetivo de exprimir as ações que o locutor pretendia fazer no futuro (habeo cantare). Na terceira fase, estes dois verbos acabaram por formar uma construção perifrástica (cantare-hei) em que os dois elementos se uniram para formar, numa $4 .^{a}$ fase, uma só palavra (cantarei) (aglutinação).

Agora vamos tentar responder à última pergunta: qual é o motivo pelo qual o valor tempoaspetual do pretérito perfeito composto se revela específico em comparação com as restantes línguas românicas? ${ }^{13}$ A primeira diferença que se pode notar é o verbo auxiliar ser diferente (ter) da maioria das línguas neolatinas, em que o mesmo tempo se forma pelo auxiliar habere. Esta hipótese, porém, carece de sustentação devido a dois contra-argumentos:

1. o mais-que-perfeito composto português é formado pelo mesmo verbo auxiliar e não exprime o valor de duratividade como o pretérito perfeito composto;

2. nalgumas variantes do Espanhol latino-americano, o pretérito perfeito composto tem valores muito semelhantes ao português e, à diferença deste, é formado pelo auxiliar haber (Brocardo 2014: 141-142).

O motivo do valor específico deste tempo em Português será diferente. Segundo vários linguistas, ele deverá procurar-se na evolução do pretérito perfeito simples na língua portuguesa. Enquanto que nas demais línguas românicas, a forma simples do pretérito perfeito tendeu a empregar-se com cada vez menor frequência em proveito da forma composta, em Português, a forma simples conservou a plena vitalidade até hoje. No Português Antigo, os dois tempos, que tinham aproximadamente o mesmo valor tempo-aspetual ${ }^{14}$, concorreram. Esta competição foi resolvida pela diferenciação semântica da variante composta que assumiu os valores de duratividade ou iteratividade de que a forma simples carecia (Brocardo 2014: 142). A semanticista portuguesa Maria Henriqueta Costa Campos acrescenta que é a coocorrência do auxiliar ter com o tempo do presente que está na base do valor específico que adquiriu o pretérito perfeito composto em Português (Cardoso e Pereira 2003: 160).

\section{Métodos de análise}

Repitamos os objetivos principais do presente artigo: 1. verificar qual o emprego dos verbos auxiliares na evolução do Português Europeu; 2. mostrar a evolução da concordância do parti-

13 O pretérito perfeito composto exprime ações que começaram no passado (geralmente não sabemos quando) e continuam até ao presente e há uma probabilidade de se prolongarem até ao futuro. Um dos seus traços principais é o seu caráter não-terminativo. Conforme o tipo de verbo, pode denotar estados (caráter durativo) ou acontecimentos que se têm repetido (caráter reiterativo) (Svobodová 2014: 75-77; Chergova 2009).

14 É muito provável que, no Português Antigo, o pretérito perfeito composto tenha tido o mesmo valor que tem o mesmo tempo no Espanhol Contemporâneo, ou seja, tenha exprimido as ações anteriores ao momento presente. Estas ações, porém, tinham sempre uma certa relação ao presente (Cardoso e Pereira 2003: 170; Brocardo 2014: 146). 
cípio com o objeto direto ou sujeito; 3 . desvendar a relação entre o tempo composto e a construção resultativa e as suas caraterísticas morfossintáticas, sobretudo no Português Antigo; 4. mostrar a evolução do significado tempo-aspetual do pretérito perfeito composto no Português Europeu.

Para tal decidimos aproveitar o corpus linguístico disponível em www.corpusdoportugues. org $^{15}$ que permite fazer pesquisas diacrónicas. Analisámos as ocorrências das estruturas seguintes: os verbos haver, ter e ser + particípio passado ([haver] ou [ter] ou [ser] [vk]) entre os séculos XIV e $\mathrm{XX}^{16}$. Tal procedimento mostrou as construções compostas dos verbos em questão em todos os paradigmas (indicativo do presente, pretérito imperfeito, pretérito perfeito simples, infinitivo etc.) e do particípio passado. No corpus apareceram sempre 100 ocorrências de várias construções (cada construção foi representada por mais exemplos, por exemplo a construção foy tornado apareceu onze vezes no corpus, foy partido quatro vezes etc.). De todos os tipos de construções, foram escolhidas 100 ocorrências com o verbo auxiliar na forma finita (a seleção foi aleatória) e estas 100 ocorrências (para cada século) foram analisadas (no caso de tal número de ocorrências aparecer no século em questão). Para podermos dividir as construções encontradas em tempos compostos e construções resultativas, decidimos usar os critérios semânticos em vez dos formais preferidos por muitos linguistas no passado (ver nota 11). A abordagem semântica tem em conta contrastes aspetuais e temporais, tais como: simultaneidade/anterioridade; perfetividade/imperfetividade (Cardoso e Pereira 2003: 166). Agora passamos a mostrar os resultados da nossa pesquisa in corpora para cada século.

\section{Análise in corpora}

\subsection{Século XIV}

O número total das ocorrências com o verbo auxiliar ser foi 2 132. A maioria dos casos foi representada pelas ocorrências da voz passiva. O tempo composto apareceu em 31 casos (16 - era viindo, 11 - foy tornado e 4 - foy partido). Em todos os exemplos, trata-se de verbos de movimento.

(1) E o cavaleyro foy a dona Orraca e disselhe como era viindo o Cide a ella em embaixada. (Crónica Geral de Espanha de 1344)

(2) Este rey dõ James, despois que foy partido da primeira molher per mandado da Igreja, como dicto avemos, casou cõ outra dona que avya nome dona Vyolante e foy filha de dõ ãdres... (Crónica Geral de Espanha de 1344)

As construções com o verbo auxiliar ter apareceram em 147 ocorrências. Do caráter das estruturas analisadas pode-se deduzir que nas 100 ocorrências selecionadas há só 25 casos do

15 O corpus elaborado por Mark Davies (BYU) e Michael J. Ferreira (Georgetown University) contém mais de 45 milhões de palavras nos textos provenientes dos séculos XIV-XX escritos em ambas as variantes principais do Português, respetivamente no Português Europeu e no do Brasil.

16 A análise in corpora foi realizada em outubro de 2016. 
tempo composto (pretérito perfeito composto ou pretérito mais-que-perfeito composto). Estas construções são caraterizadas pelos traços temporal de anterioridade e aspetual de perfetividade $(\text { ex. } 3,4,5)^{17}$. Acrescente-se que em todas as ocorrências do tempo composto, o particípio passado concorda com o objeto direto (ex. 4).

(3) E, se eu per ventuira a elle posso chegar, eu me cuydo a vyngar do torto que nos tem feito e das sobervhas que ha ditas contra nos, ca elles nõ sõ tam boos como nos, como quer que nos sejamos poucos, ca os seus maaos fugiram e farã aos outros boos fazer mal e fugir; (Crónica Geral de Espanha de 1344)

(4) E dhy partyo logo pera Bizcaya, que tiinha prometida ao iffante dõ Johã, seu primo. (Crónica Geral de Espanha de 1344)

(5) Mays a m“j semella que nos ualería mays de nós seer todos mortos, ante que sofrer tal torto et tal onta, qual delles temos rreçebudo. (Crónica Geral de Espanha de 1344)

Os 75 restantes casos são construções resultativas. O seu caráter típico é o de imperfetividade e simultaneidade (ex. 6 e 7 ).

(6) E esto por escãybo de terra de Toronho e d'Aliste que Portugal tiinha ë Galiza e doutros logares que Castella tiinha tomados des o tempo del rey dom Affonso, o primeiro rey de Portugal, e de dom Sancho, seu filho. (Crónica Geral de Espanha de 1344)

(7) Em quanto el rei tiinha cercada esta cidade, acaeceu que hûû bispo de Grecia leixara o bispado por mais livremente servyr a Deus e veeo ë romaria a Santiago. (Crónica Geral de Espanha de 1344)

No que diz respeito às construções com o verbo auxiliar haver, verificámos que no corpus não tinha aparecido nenhuma estrutura resultativa. O número total deste tipo de construções foi de 769. Todas as ocorrências analisadas representaram, assim, tempos compostos. Só em três casos, não se realizou a concordância do particípio com o objeto direto (ex. 10).

(8) E Tarife disse que faria todo o que lhe elle consselhasse, ca elle nõ avya feita në hûa cousa sen seu conselho. (Crónica Geral de Espanha de 1344)

(9) Quando o conde ouve acabada sua razon, como avees ouvido, ficaron todos muy confortados. (Crónica Geral de Espanha de 1344)

(10) A iija. rregla ha hûã contraridade \& he esta como quando acussasse algûû bispo dante seu arcebispo que auia feito tal cousa per que deuesse a perder o bispado. (Afonso X, Primeyra Partida)

Dos exemplos analisados pode-se deduzir que no século XIV (à diferença do que acontece no Português Contemporâneo), o pretérito perfeito composto, ou com o verbo auxiliar ter, ou

17 Nalguns exemplos foi muito difícil decidir a que categoria pertence uma frase analisada devido à falta de traços formais ou semânticos. Classificámos este tipo de frases como construções resultativas ("Ora vos queremos contar quanto tempo o muy nobre rey dom Fernando teve cercada Sevilha”, Crónica Geral de Espanha de 1344). 
com o haver, exprimia processos anteriores ao momento da enunciação ${ }^{18}$ (ex. 3, 5, 9). Nalguns exemplos, o pretérito perfeito composto exprimia um processo pretérito com uma relação evidente ao presente (ex. 5) (Cardoso e Pereira 2003: 169).

\subsection{Século XV}

O número total de ocorrências das construções compostas do verbo auxiliar ser e do particípio passado foi 3 023. É interessante que não tenhamos encontrado nenhum exemplo do tempo composto. Todas as ocorrências representam, assim, a voz passiva (ex. 11).

(11) Assi como vos eu digo foi feita a Fonte da Guariçom que ainda dura assi como vós já sabedes. (A Demanda do Santo Graal - cópia do século XV)

As estruturas compostas do verbo auxiliar ter e do particípio passado foram representadas por 266 casos na totalidade. No item das 100 ocorrências analisadas, há 93 casos do tempo composto e 7 exemplos de construção resultativa. Como se pode ver nos exemplos 12 e 13, o pretérito perfeito composto formado pelo auxiliar ter exprime os processos anteriores ao momento da enunciação.

(12) E o batell do cardeall estava em meo antre os batees dos rreis, prazendo- -lhe muito da boa aveença que viia antr'elles: e jurados alli os trautos pellos rreis, os quaaes ja teendes ouvido, e falladas todallas cousas que lhe compriam, espedirom-sse huu do outro, e rremarom os batees cada huu pera hu partira. (Fernão Lopes, Crónica de Dom Fernando)

(13) E muyto poderosso Rey nosso senhor dizem vossos pouoos que Ja asaz tem fallado e apontado nos capitollos atras do rregimento e gouernança de vossa fazenda. (Cortes portuguesas, 1498)

À diferença do século anterior, encontrámos 6 ocorrências do tempo composto em que o particípio não concorda com o objeto direto (ex. 12).

No que diz respeito às construções resultativas, no corpus apareceram os exemplos que, observando os seus traços formais e semânticos (concordância, expressão do estado) podemos ter classificado como tais sem qualquer dúvida (ex. 14), mas também houve alguns casos em que foi muito difícil decidir do tipo de construção (estrutura resultativa/tempo composto) (ver nota 18) (ex. 15).

(14) Os portugueses se acolherã na çerca velha. El rey de Castela teve çercada Lixboa per mar e per terra algûus dias. (História dos Reis de Portugal, em Crónica Geral de Espanha de 1344)

(15) E esta partida dizem que foi per mandado d'elrrei de Castella, que tiinha cercada Almeida, como dissemos; e quando foi certo da viinda dos ingreses, mandou chamar estas gentes que se vehessem per'eelle: (Fernão Lopes, Crónica de Dom Fernando) 
O número total das ocorrências da construção composta do verbo auxiliar haver e do particípio passado foi 527. Nos 100 casos analisados não foi encontrada nenhuma construção resultativa. O pretérito perfeito composto com este verbo auxiliar exprime sempre uma ação anterior ao momento da enunciação. Nalguns exemplos, este tempo exprime um processo pretérito com uma relação ao presente (ex. 16).

(16) E eu estando catando-o sobreveo i meu irmão, o conde de Geer, e trousse-me mal e matei-o. Todo este mal que te eu digo, eu hei feito em ûû soo dia. Ora me conselha, padre santo, ca já tam grande pendença nom me darás que a eu nom tenha. (A Demanda do Santo Graal cópia do século XV)

(17) E Galaaz, quando esto golpe houve feito, disse: Cavaleiro, bem vos aveeo que nom sodes chagado; e bem me é em, assi Deus me valha, ca bem cuido que sodes bõõ cavaleiro. ( $A$ Demanda do Santo Graal - cópia do século XV)

Encontrámos 15 casos (dos 100 analisados) em que o particípio passado não concorda com o objeto direto (ex. 18).

(18) E, como o despemselro se maravilhase desto, comtaromlhe os fraires todalas cousas que o leom avia feito, acompanhamdoos por o caminho. (Crónica da Ordem dos Frades Menores, 1209-1285)

\subsection{Século XVI}

Na secção do século XVI, o corpus encontrou 2223 ocorrências da construção formada pelo verbo ser e particípio passado. Em todas as ocorrências desta estrutura, registámos 143 exemplos do tempo composto (com os verbos seguintes: chegar, ir, partir, vir e falecer). Acrescente-se que todos estes casos representam o mais-que-perfeito composto e realiza-se sempre a concordância do particípio passado com o sujeito (ex. 19 e 20).

(19) Porque Afonso de Albuquerque veo àquele lugar com ter aviso per seu sobrinho D. António do número da gente que ali estava, e não sabia que aquela tarde do dia passado era chegado um capitão del-Rei de Lara com trezentos frecheiros, que causou serem os nossos metidos em tanto perigo. (João de Barros, Décadas da Asia - Década Segunda, Livros $\mathrm{I}-\mathrm{X})$

(20) E posto que estes o animaram muito pera aquele feito a que vinha, quando soube deles como Pate Quetir era partido pera a Jaua, e o modo como foi desbaratado, ficou mui triste e confuso, porque no conselho dele tinha posto grande parte de sua esperança, e, como homem novo na terra, achou-se manco de todo. (João de Barros, Décadas da Asia - Década Segunda, Livros I-X)

O número total das ocorrências das estruturas compostas pelo verbo auxiliar ter e particípio passado é de 2 263. Nos 100 casos analisados, não encontrámos nenhuma construção resul- 
tativa. Só em 5 casos de tempo composto deparámos com a concordância do particípio com o objeto direto (ex. 21).

(21) O Papa lhe outorgou todo esto e outras mais cousas que lhe enviou pedir, dando-lhe grandes perdões e indulgencias para as Igrejas que ali tinha feitas. (Duarte Galvão, Cronica de D. Afonso Henriques)

Neste século, começa a usar-se também o auxiliar ter com os verbos de movimento (ex. 22). Nos séculos anteriores, neste contexto aparecia exclusivamente o verbo auxiliar ser.

(22) E tres ou quatro dias antes tinha chegado de Bungo o Irmão Ayres Sanches, com sinco ou seis meninos japões e chinas, que o mesmo Irmão tinha ensinados a tanjer violas d'arco, e sabião já officiar huma missa -e tanjião arrezoadamente. (Frois, Historia do Japam 1)

Registámos também alguns exemplos em que o pretérito perfeito composto exprime as ações que estão relacionadas ao presente ou cujos resultados se refletem no presente (ex. 23 e 24).

(23) O triste de mim! Que tenho feito! Com que salvarei minha fama, pois a vendi por tão pequeno preço? (João de Barros, Crónica do imperador Clarimundo)

(24) Mas ja lhe tenho dito a causa que me obriga a fazer primeiro esta jornada, e des hi se algum impedimento me não desvia, eu lhe tornarei a obedecer em tudo o que me mandar, e eu com razão possa fazer. (João de Barros, Crónica do imperador Clarimundo)

No corpus, encontrámos 227 ocorrências da construção formada pelo verbo auxiliar haver e particípio passado. O número real deste tipo de estruturas é muito mais baixo, visto que, no corpus, apareciam muitos casos que não cumpriam os critérios da nossa pesquisa como, por exemplo, frases fixas (haver vista) ou frases escritas em Castelhano (provenientes dos escritores que escreviam em ambas as línguas - Gil Vicente). Analisámos, assim, só 51 ocorrências deste tipo de construções. Não encontrámos nenhuma construção resultativa. A concordância do particípio passado com o objeto direto apareceu só em 6 casos (ex. 25).

(25) A primeyra noyte quando chegarom hy virom muytos fogos por causa dos nauios christãos que jamais auiam vistos. (Códice Valentim Fernandes)

(26) E como os messegeiros fezessem o que elle mandava, chegando ao carcere, vierom a sancta Guiteria com muito povoo, aos quaes ella dizia como Deos lhe havia feito muita graça e como estando em aquelle carcere havia dado saude a muitas gentes de muitas e diversas enfermidades por virtude de Jhesu Christo meu Senhor, como alumiara muitos cegos e a muitos mancos levantando em seus pees e de outras muitas enfermidades havia dado saude. (Flos sanctorum)

(27) ...e da dita altura por diante se governe de maneira que se va a oeste da Ilha de João da Nova 10 ou 12 leguas, da qual paragem se fara o governo que se ha dito atras para ir demandar a terra de Moçambique. (Dois roteiros do século XVI) 


\subsection{Século XVII}

O número total das ocorrências da construção composta do verbo ser e particípio passado é de 899. Deste número, só 66 casos representam tempo composto, as ocorrências restantes são exemplos da voz passiva (833 casos). Trata-se sempre dos tempos compostos dos verbos de movimento (chegar, fugir, partir). Nestas construções realiza-se sempre a concordância do particípio passado com o sujeito (ex. 28).

(28) Lá me levarão novas que era chegada a armada que foy buscar a frota de Cambaya a salvamento, e que encontrara as duas naos de Olanda que andão defronte desta barra a huma vista; (Diario do Conde de Sarzedas)

(29) Não é chegado o correio, que como escrevi a V. S. é de muita expectação. (Padre António Vieira, Cartas)

No que diz respeito às construções com o verbo auxiliar ter, encontrámos 1669 ocorrências. Todos os casos encontrados representam os tempos compostos (nenhuma construção resultativa foi detetada). Neste século, o particípio passado nunca concorda com o objeto direto. Em termos dos conteúdos temporais e aspetuais do pretérito perfeito composto, podemos constatar que, em comparação aos séculos anteriores, o leque de significados se ampliou consideravelmente. Além da expressão dos processos passados, o que era típico nos séculos anteriores (ex. 30), este tempo serve também para denotar ações iterativas (ex. 31 e 32) ou aquelas que se prolongam até ao presente (ex. 33).

(30) Eles cuidaram que o morto falava e com medo largaram a tumba e sucedeu a este tempo o que já tenho dito. (Gaspar Pires Ribelo, Infortunios trágicos da constante Florinda)

(31) As dos negócios daqui verá V. Ex. a, pela carta do Sr. Embaixador, que verdadeiramente são hoje maiores que nunca, e com mais sólidos fundamentos: queira Deus que nos não mintam, como tantas vezes têm feito. (Padre António Vieira, Cartas)

(32) Por varias vias tenho escrito a V. Ex.a, e respondido a todas as suas cartas ate vinte seis de Agosto. (Marquês de Sande, Cartas)

(33) Tal é a sabedoria da Igreja, entrando sempre nela as puríssimas correntes da doutrina de tantos Doutores católicos e sapientíssitnos, que cada dia a aumentam com novos e tão excelentes escritos em uma e outra teologia, de que o nosso século tem sido mais fecundo e abundante que todos até hoje. (Padre António Vieira, Historia do Futuro)

No corpus, encontrámos 536 ocorrências das construções com o verbo auxiliar haver. Em todos os casos, trata-se de tempos compostos (nenhuma construção resultativa). Nunca se realiza a concordância do particípio com o objeto direto. Os significados do pretérito perfeito composto são semelhantes ao mesmo tempo formado com o auxiliar ter, ou seja, expressão dos processos pretéritos (ex. 34), ações iterativas (ex. 36 e 37) ou aquelas que duram até ao momento presente (ex. 38). 
(34) Ao navio S. Vicëte, seguião todos os mais Dunquerquezes de aquella Armada; despois a esquadra de São Josef, de que atràs havemos feito menção, governada de seu Almirante Francisco Sãches Guadalupe, com doze navios os melhores da Frota, debaxo de sua cõduta. (Francisco Manuel de Melo, Epanaphora politica primeira)

(35) E o perjuro cristao, vendo-se assim confundido e envergonhado, se volveu e tornou a sua casa e tomou a metade de seus bens e os ofereceu ao santo e, arrependendo-se grandemente de seu pecado, chorou e sentiu muito o que havia feito e viveu em aquele templo fazendo penitência e outros serviços a Deus, até que morreu e alcançou perdao, por intercessao do santo mártir. (Francisco Saraiva de Sousa, Báculo pastoral de flores)

(36) Os que vivem em casa dos portugueses têm demais os cativeiros injustos, que muitos deles padecem, de que V. M. tantas vezes há sido informado, e que porventura é a principal causa de todos os castigos que se experimentam em todas as nossas conquistas. (Padre António Vieira, Cartas)

(37) Mas jà despois de segurada a gente, E o tûmulto das vozes sossegado, Suspença a admiração, que de repente Aós casos mais silençio sempre há dado, O forte Capitão sabio, e prudente, Pello pilóto auendo perguntado, Lhe rogou que contasse donde vinha, E que derrota em seus intentos tinha. (Manoel Thomas, Insulana)

(38) Donde vem, que nenhum Varão sábio deve tomar parte neste genero de serviço, que de ordinario tras aos homens que o seguem, trabalhosos fins; de que entre nòs, em os tempos presentes havemos visto tão lastimosos exemplos; porque o verdadeiro juizo dos coraçoens humanos, he reservado só a Deos. (Francisco Manuel de Melo, Epanaphora politica primeira)

\subsection{Século XVIII}

O número total das ocorrências da construção composta do verbo ser e particípio passado é de 930. Neste século, deparámos com apenas 5 casos do tempo composto, respetivamente na forma era chegada que funcionou como mais-que-perfeito (ex. 39). As demais ocorrências desta construção representam a voz passiva.

(39) A este tempo Delmetra estava ouvindo com grande alegria aquela repentina mudança da fortuna: e como quási era chegada a noite, Antionor, fazendo aquí ponto, se despediu; (Teresa Margarida da Silva e Orta, Aventuras de Diófanes)

O número total das ocorrências da construção composta do verbo auxiliar ter e particípio passado é de 1 150. Nunca o particípio concorda com o objeto direto. Não encontrámos nenhuma construção resultativa. À diferença dos casos com o verbo auxiliar haver, a proporção das ocorrências do pretérito perfeito composto e mais-que-perfeito composto é relativamente igual. O pretérito perfeito composto costuma denotar os processos anteriores ao momento da enunciação (ex. 40) e às vezes as ações repetidas (ex. 41). 
(40) A cima temos ditto no primeiro Capitulo deste Livro; que a nossa Lingua excede a todas na abundancia, que tem de nomes augmentativos, e na facilidade com que os forma. (José de Macedo (assinado por António Melo da Fonseca), Antídoto da língua portuguesa)

(41) Um assopro indiscreto sobre uma cabeleira artificiosamente penteada e polvilhada tem produzido muitas vezes uma inquietaçao, um desgosto e uma mortificaçao inexprimível. (Francisco Xavier de Oliveira, Cartas familiares)

No que diz respeito ao verbo auxiliar haver, no corpus apareceram 298 ocorrências deste tipo de construção. Não encontrámos nenhuma estrutura resultativa e nenhum caso em que se realizasse a concordância do particípio com o objeto direto. Em todas as ocorrências, deparámos só com 17 exemplos do pretérito perfeito composto. Analisando estes casos, podemos constatar que este paradigma exprime sempre os processos anteriores ao momento da enunciação. Como vimos nos séculos anteriores, às vezes deparamos com casos em que a ação expressa por este tempo tem uma relação com o momento presente (ex. 42) ou o tempo denota um processo iterativo (ex. 43). As restantes ocorrências desta construção são exemplos do mais-que-perfeito composto (44).

(42) Não menos declara o tom de sua voz a letra $\mathrm{O}$, de que havemos dito das outras vogaes, porque a fórma deste caracter significa a propria figura, que fas a bocca, [144] quando a pronunciamos. (Francisco Manuel de Melo, Tratado da sciencia cabala, ou Noticia da arte cabalistica)

(43) Mas sem que para provar a virtude energiaca da Musica necessitemos do testemunho da antiguidade, he mayor de toda a exceyção a cura, que muytas vezes havemos visto ministrar aos feridos da Tarantula, animal pequeno, quasi aranha, de q' se achão muytos em Apulia... (Francisco Manuel de Melo, Tratado da sciencia cabala, ou Noticia da arte cabalistica)

(44) ...uns raspavam a terra, outros como rosnando se chegavam tanto, que pegando com os dentes no pano, que me cobria, me voltavam de uma parte para a outra, e ficava eu imóvel no mesmo lugar, onde havia caído. (Teresa Margarida da Silva e Orta, Aventuras de Diófanes)

\subsection{Século XIX}

O número total das ocorrências da construção composta do verbo ser e particípio passado é de 2 458. Encontrámos só 18 casos do tempo composto ( 9 - é chegado, 7 - era chegada, 2 - era chegado). Acrescente-se que o sujeito dos tempos compostos com o auxiliar ser é quase exclusivamente inanimado (ex. 45 e 46). As restantes ocorrências representam a voz passiva.

(45) Sim meus amigos. Já o tempo é chegado. (Almeida Garrett, Teatro)

(46) Senti que era chegada a minha hora, pareceu-me que ia ser expulso daquele Éden de inocência em que tinha vivido. (Almeida Garrett, Viagens)

No que diz respeito às construções formadas pelo verbo auxiliar ter, no corpus apareceram 5974 ocorrências na totalidade. O particípio nunca concorda com o objeto direto. Da análise 
dos exemplos do pretérito perfeito composto pode-se deduzir que, neste século, o paradigma já adquiriu o significado tempo-aspetual que tem no Português Contemporâneo, ou seja, denota uma ação que começou no passado e continua na época presente com uma eventualidade de se prolongar até ao futuro (ex. 47, 48, 49 e 50) ${ }^{19}$. Nos 100 exemplos analisados, não encontrámos nenhuma construção resultativa.

(47) Sente-se aqui, Sr. padre Amaro. Amaro pousou-se à beira dum fauteuil, com o seu guardasol na mão, - e reparou então numa senhora alta que estava de pé, junto do piano, falando com um rapaz louro. - Que tem feito estes dias, Amaro? disse a condessa. Diga-me uma coisa: sua irmã? (Eça de Queirós, O Crime do Padre Amaro)

(48) Ó Sebastião, um rapaz alto, que eu tenho visto todos estes dias entrar para casado Jorge, é o Basílio de Brito, pois não é? (Eça de Queirós, O Primo Basílio)

(49) Até que finalmente a encontro, Berta. Quase me tinha chegado a convencer de que uma fatalidade ou um propósito nos separava. Há tanto tempo que não conseguia vê-la! - E procuravame, Sr. Maurício? - Todos os dias o tenho feito. (Júlio Dinis, Os Fidalgos da Casa Mourisca)

(50) O Ega deve estar radiante, dizia Carlos com os pés à chama. Tem, enfim, justificada a peliça. A propósito, algum dos senhores tem visto o Ega estes últimos dias? Ninguém respondeu, no interesse súbito que causava a cartada. (Eça de Queirós, Os Maias)

No corpus apareceram 1572 construções com o verbo auxiliar haver na totalidade. Em todas as ocorrências, encontrámos 22 casos do pretérito perfeito composto. A análise semântica destes exemplos mostrou que este paradigma, também no século XIX, serve para exprimir as ações anteriores ao momento da enunciação (ex. 51 e 52). Os demais casos representam o mais-queperfeito composto. Estes exemplos são muito mais frequentes no Português do Brasil do que no Português Europeu. Tal como nas estruturas com o auxiliar ter, também nestes casos nunca se realiza a concordância do particípio com o objeto direto.

(51) A bala resvalou, - e já sem força, Leve aqui me feriu na sestra face, E fria aos pés me cai » - « Leve ferida Que um dos olhos.. » - « Oh! dous nos há dado Liberal natureza. (Almeida Garrett, Camões)

(52) «Se é crime » continuou « ter alma e vista, Foi essa a única ofensa que lhe hei feito ao vingativo conde. (Almeida Garrett, Camões)

\subsection{Século XX}

Na secção do século XX, não encontrámos nenhum tempo composto formado pelo verbo auxiliar ser (da totalidade de 16204 ocorrências). Todos os exemplos representaram, assim, a voz passiva.

As construções formadas pelo verbo auxiliar ter e particípio passado apareceram no número de 15 473. Nas 100 ocorrências analisadas, não foi encontrada nenhuma construção resultativa.

19 O primeiro linguista que se deu pelo facto de o pretérito perfeito composto português ter o significado tempoaspetual diferente às restantes línguas românicas, foi, no início do século XX, o foneticista português Gonçalves Viana que o denominou "prétérit itératif" (Boléo 1936: 4). 
Todos os exemplos do pretérito perfeito composto mostram que o paradigma tem o significado tempo-aspetual atual (ver no capítulo anterior) (ex. 53 e 54).

(53) ...o empregado procura espaço para pousar a chávena e o copo de água, põe o pacote de açúcar no pires, e antes de retirar-se repete o comentário que tem feito ao longo da manhã, fala do frio que está... (José Saramago, História do Cerco de Lisboa)

(54) O combate ao tráfico de estupefacientes, as infracções económico-financeiras e os ilícitos lesivos de pessoas e do património são algumas das prioridades definidas para Inspecção de Leiria da Polícia Judiciária, que desde o início deste ano tem estado em fase de instalação. (Droga na prioridade da PJ, 12/9/1997)

O número total das construções com o auxiliar haver é de 2285 . Todas as ocorrências representam tempos compostos. $\mathrm{O}$ mais-que-perfeito composto foi o tempo de longe mais frequente (nomeadamente no Português do Brasil - ex. 55). Não deparámos com nenhum caso do pretérito perfeito composto.

(55) Delineou, em 1977, a estrutura de uma nova constituição na qual os limites de discordância interna estavam claramente demonstrados, e em 1968, foi também promulgada a " doutrina de Brezhnev », que estabelecia o direito da URSS intervir na Europa de leste para "preservar o socialismo », tal como já havia feito na Checoslováquia. (União das Repúblicas Socialistas Soviéticas)

\section{Apresentação dos resultados da análise in corpora}

Tendo analisado o emprego dos verbos auxiliares no corpus www.corpusdoportugues.org na evolução da língua portuguesa, podemos agora sumarizar alguns resultados da nossa pesquisa. A tabela 1 mostra a percentagem da ocorrência de cada verbo auxiliar no período analisado, ou seja, no período abrangido entre o século XIV e o XX. Os mesmos resultados são apresentados também no gráfico 1 .

\begin{tabular}{|l|c|c|c|}
\hline século & \multicolumn{3}{|c|}{ Ocorrência do verbo auxiliar (\%) } \\
\hline & ser & ter & haver \\
\hline século XIV & 3,7 & 4,4 & 91,9 \\
\hline século XV & 0,0 & 31,9 & 68,1 \\
\hline século XVI & 5,8 & 92,1 & 2,1 \\
\hline século XVII & 2,9 & 73,5 & 23,6 \\
\hline século XVIII & 0,4 & 79,0 & 20,6 \\
\hline século XIX & 0,2 & 79,0 & 20,8 \\
\hline século XX & 0,0 & 87,1 & 12,9 \\
\hline
\end{tabular}

Tabela 1 A percentagem da ocorrência dos verbos auxiliares 


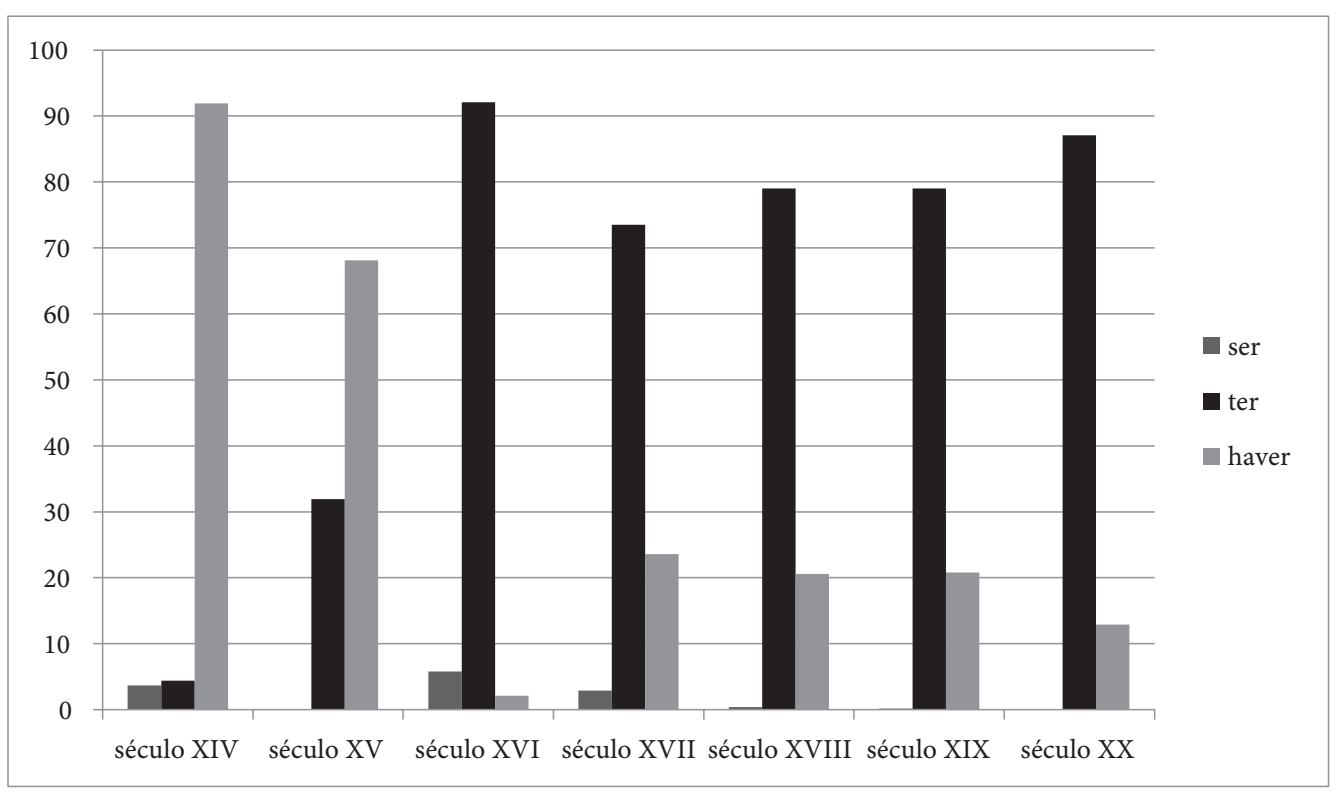

Gráfico 1. A percentagem da ocorrência dos verbos auxiliares

Na tabela 2 e no gráfico 2 apresenta-se a percentagem da ocorrência da concordância do particípio passado com o objeto direto ou sujeito em cada verbo auxiliar ${ }^{20}$.

\begin{tabular}{|l|c|c|c|}
\hline século & \multicolumn{3}{|c|}{$\begin{array}{r}\text { Ocorrência da concordância do particípio passado com } \\
\text { o objeto direto ou sujeito (\%) }\end{array}$} \\
\hline & ser & ter & haver \\
\hline século XIV & 100 & 100 & 99,6 \\
\hline século XV & $\star$ & 93,5 & 85 \\
\hline século XVI & 100 & 5 & 11,8 \\
\hline século XVII & 100 & 0 & 0 \\
\hline século XVIII & 100 & 0 & 0 \\
\hline século XIX & 100 & 0 & 0 \\
\hline século XX & $\star$ & 0 & 0 \\
\hline
\end{tabular}

Tabela 2. A percentagem da ocorrência da concordância do particípio passado com o objeto direto ou sujeito 


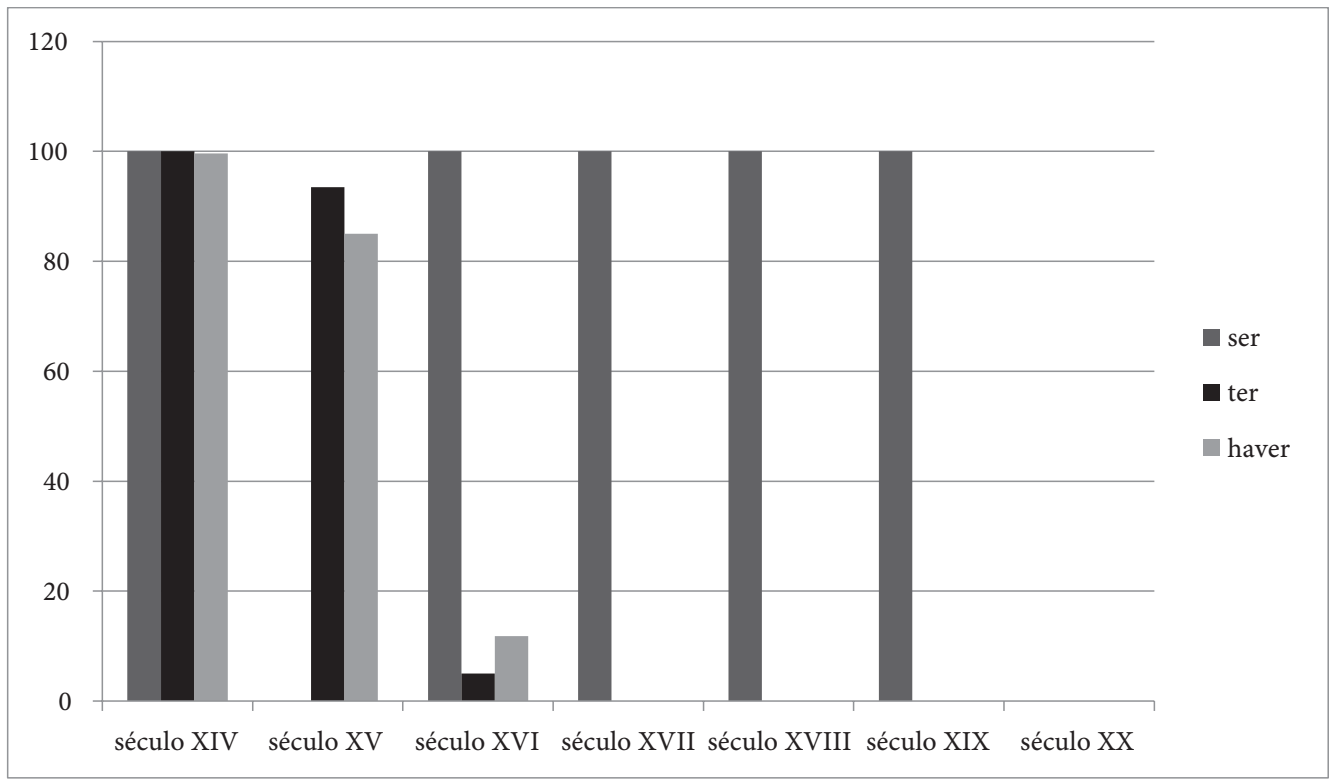

Gráfico 2. A percentagem da ocorrência da concordância do particípio passado com o objeto direto ou sujeito

\section{Conclusões}

Para concluir, vamos tentar responder às perguntas propostas na parte introdutória deste artigo, apoiando-nos nos resultados da nossa pesquisa in corpora. No que diz respeito à evolução do emprego dos verbos auxiliares na língua portuguesa, podemos constatar que o auxiliar ser nunca se usava com uma frequência elevada, mas o seu emprego, apesar de passar a ser cada vez mais esporádico, persistiu até ao século XIX. No século XX, já não foi encontrado nenhum exemplo do tempo composto formado por este auxiliar. Este verbo serviu de auxiliar exclusivamente com os verbos de movimento (vir, tornar, partir, chegar, ir) ou intransitivos (falecer). $\mathrm{O}$ verbo ter começou a ser empregue como auxiliar duma maneira sistemática só no século XV, enquanto que, no século anterior, empregava-se nomeadamente em construções resultativas. Desde o século XVI, a sua frequência como verbo auxiliar vai crescendo, sendo empregue também com os verbos de movimento (em vez do auxiliar ser). O verbo auxiliar haver era muito mais frequente do que o auxiliar ter nos séculos XIV e XV. Desde o século XVI, o seu empre西 go, nesta função, começa a diminuir, sendo usado quase exclusivamente no mais-que-perfeito composto. É só no século XX que não encontrámos nenhum pretérito perfeito composto formado por este auxiliar. É interessante que não tenha sido encontrada nenhuma construção resultativa formada por este verbo. Além dos objetivos deste inquérito, foi detetado que no Português Moderno o auxiliar haver é muito mais típico do Português do Brasil do que da variante europeia. Acrescente-se que os resultados da nossa pesquisa in corpora correspondem àqueles constatados por outros linguistas (Brocardo 2014; Berta 2016). 
Analisando a concordância do particípio passado com o objeto direto ou sujeito, a nossa pesquisa mostrou que nos séculos XIV e XV, nos tempos compostos formados pelos auxiliares ter e haver, a concordância foi muito frequente, enquanto que no século XVI esta tornou-se esporádica. Desde o século XVII, o particípio passado nunca concorda com o objeto direto. Nos tempos compostos formados pelo auxiliar ser, o particípio concorda sempre com o sujeito da frase.

No que diz respeito à relação entre tempos compostos e construções resultativas no Português Antigo, os resultados da nossa pesquisa provaram parcialmente as conclusões de Tibor Berta (ver acima). No século XIV, o verbo ter empregava-se nomeadamente para formar construções resultativas, enquanto que haver em tempos compostos (nenhuma construção resultativa encontrada). Com a propagação do verbo ter como auxiliar em tempos compostos desde o século XV, a concordância participial começa a diminuir (no século XVI) para desaparecer por completo no século seguinte. Segundo Tibor Berta, este facto é muito importante para os locutores poderem distinguir entre tempo composto (não-concordância) e construção resultativa (concordância), sendo desde aí ambas as estruturas formadas frequentemente pelo mesmo verbo auxiliar ter.

No que toca à evolução do significado tempo-aspetual do pretérito perfeito composto, podemos constatar que, desde o século XIV até ao século XVII, este paradigma denotava exclusivamente os processos ocorridos antes do momento da enunciação, ou seja, pretéritos, ou eventualmente aqueles que tinham uma relação ao presente. No século XVIII, este tempo começa a exprimir também ações iterativas (acompanhado pelos advérbios deste sentido). No século XIX, o pretérito perfeito composto formado pelo auxiliar ter adquire o significado tempo-aspetual que tem no Português Contemporâneo, enquanto que o mesmo tempo formado pelo auxiliar haver, cuja frequência já é baixa, continua a ter o mesmo significado como nos séculos anteriores. No século XX, o verbo auxiliar haver já não se emprega para formar este paradigma. No presente artigo, este aspeto pode não ter sido tratado duma maneira pormenorizada. A análise mais detalhada deste interessante tema fica, assim, por ser feita.

\section{Referências bibliográficas}

Berta, T. (2016). Contribuição para a história da eliminação da concordância do particípio nos tempos compostos do Português. In J. C. Ramos, Š. Grauová, \& J. Jindrová (Eds.), Língua portuguesa na Europa central: estudos e perspetivas (pp. 174-183). Praha: Karolinum.

Boléo, M. de P. (1936). O Perfeito e o Pretérito em Português em confronto com as outras línguas românicas. Coimbra: Biblioteca da Universidade.

Brocardo, M. T. (2014). Tópicos de História da Língua Portuguesa. Lisboa: Edições Colibri.

Cardoso, A., \& Pereira, S. (2003). Contributos para o estudo da emergência do tempo composto em Português. Revista da Abralin - Associação Brasileira de Linguística, 2(2), 159-181.

Chergova, V. (2009). Particularidades do Sistema Verbal Português no Indicativo. Étude Romanes de Brno, 30(1), 197-209.

Costa, M. J. (2010). Os verbos "aver" e "teer" no português arcaico - breve sinopse. Filologia linguística portuguesa, 12(1), 59-68. 
Hricsina, J. (2014). O verbo auxiliar tenere nas línguas românicas. In Y. Andreeva (Coord.), Horizontes do Saber Filológico (pp. 165-173). Sófia: Editora Universitária Sveti Kliment Ohridski. . (2015). Vývoj portugalského jazyka. Praha: Karolinum.

Mattos E Silva, R. V. (1989). Estruturas trecentistas. Maia: Imprensa Nacional - Casa da Moeda.

Raposo, E. P. et alii. (2013). Gramática do Português - Volume I. Lisboa: Fundação Calouste Gulbenkian.

Ribeiro, I. (1996). A formação dos tempos compostos: a evolução histórica das formas ter, haver e ser. In I. Roberts, \& M. Kato (Eds.), Português brasileiro: uma viagem diacrônica: homenagem a Fernando Tarallo (pp. 343-386). Campinas: Editora da Unicamp.

Said Ali, M. (2001). Gramática Histórica da Língua Portuguesa. São Paulo: Editora Melhoramentos.

Svobodová, I. (2014). Morfologie současného portugalského jazyka II. Sloveso. Brno: Masarykova univerzita. Teyssier, P. $\left(2001^{8}\right)$. História da Língua Portuguesa. Lisboa: Sá da Costa.

Williams, E. B. $\left(1986^{4}\right)$. Do Latim ao Português. Rio de Janeiro: Tempo brasileiro. 